\title{
GLOOMY IMAGES OF YELLOW AND ŻÓŁTY IN A CORPUS-BASED COGNITIVE STUDY
}

\author{
EWA GIEROŃ-CZEPCZOR \\ PWSZ, Racibórz \\ ewa_g-cz@wp.pl
}

\begin{abstract}
The paper reports on a comparative corpus-based semantic analysis of one colour term as it is used in two languages: English yellow and Polish żótty. The investigation of central and peripheral meanings, based on analyses of corpus concordances draws upon the methodology and constructs of cognitive linguistics, such as prototype-based categories, domains, conceptual metonymy and metaphor. The first objective of this parallel study is to determine the prototypical reference points for yellow and zólty, followed by descriptions of those motivations and mechanisms of meaning extensions which lead to 'figurative' usages. The results are tentatively suggested in the form of a general network of related meanings, the entrenchments of which are established on the basis of frequencies attested in samples of 1,500 citations.

The outcomes confirm a conceptual proximity reflected in the semantics of these colour terms, which seems to be - perhaps surprisingly - incongruous with the popular association of yellow/zólty with the sun. As the evidence provided by the British National Corpus and the Polish Scientific Publishers' corpus (PWN) reveals, the central and peripheral readings are inspired by the imagery of autumnal and physiological changes, while the semantics of both yellow and żolty reflect the significant influence of cultural factors, unparalleled in the polysemies of the other five basic colour terms.
\end{abstract}

Keywords: colour terms, semantics, pragmatics, metaphorical extension

\section{Rationale}

My interest in yellow and żótty as cognitive categories arises out of a wider research project into the semantics of six colour terms in English and Polish (Gieron-Czepczor 2008; 2010; forthcoming). These terms: white, black, red, blue, yellow and green known as primary basic colour terms since the formulation of the thesis of universality of certain colour terms (Berlin \& Kay, 1969 - are placed at the top of the implicational hierarchy which is believed to reflect evolutionary trends and their distribution in languages. According to the theory, yellow and its Polish counterpart źótty are ranked high among these six colours exhibiting the highest frequencies and salience in fully developed, i.e. VII stage (ibid.: 22f.), languages (see Fig.1). 


$$
\begin{aligned}
& \text { black } \\
& \text { white }
\end{aligned}<\text { red }<\text { gellow }<\text { blue }<\text { brown }<\begin{aligned}
& \text { purple } \\
& \text { pink } \\
& \text { orange } \\
& \text { grey }
\end{aligned}
$$

Fig. 1: The implicational hierarchy as proposed be Berlin \& Kay (1969: 4).

In detailed quantitative research, however, yellow and żótty prove problematic in relation to this neat hierarchy. As raw corpus statistics for these BCTs indicate, both yellow and żólty are arguably unpopular (see Table 1).

\begin{tabular}{|r|l|l|r|r|c|}
\hline & Basic colour terms & $\begin{array}{l}\text { BYU- } \\
\text { BNC } \\
100 \\
\text { million }\end{array}$ & $\begin{array}{l}\text { COCA } \\
360 \\
\text { million }\end{array}$ & $\begin{array}{l}\text { PELCRA } \\
93 \\
\text { million }\end{array}$ & $\begin{array}{l}\text { PWN } \\
40 \\
\text { million }\end{array}$ \\
\hline 1. & WHITE, BIAŁY & 23,427 & 167,927 & 16,249 & 10,518 \\
\hline 2. & BLACK, CZARNY & 23,864 & 145,546 & 14,014 & 8,934 \\
\hline 3. & RED, CZERWONY & 14,568 & 71,675 & 10,658 & 6,356 \\
\hline 4. & GREEN, ZIELONY & 14,199 & 54,425 & 6,469 & 5,700 \\
\hline 5. & YELLOW, ŻÓŁTY & 4,366 & 21,971 & 3,477 & 1,799 \\
\hline 6. & BLUE, NIEBIESKI & 10,059 & 47,904 & 3,499 & 1,772 \\
\hline 7. & BROWN, BRAZZOWY & 8,383 & 49,175 & 1,668 & 953 \\
\hline 8. & GREY & 5,456 & 3,159 & 4,271 & 1,961 \\
& GRAY & 1,091 & 22,914 & & \\
\hline 9. & ORANGE, & 2,547 & 26,073 & & 707 \\
\hline 10. & POMARPLE, FIOLETOW & 1,262 & 7,483 & 730 & \\
\hline 11. & PINK, RÓŻOWY & 3,150 & 13,212 & 1,313 & 832 \\
\hline
\end{tabular}

Tab. 1: Frequencies of the 11 BCTs in electronic corpora (May 2008).

The same results, with the omission of surnames in the English and American data (see Table 2), further substantiate the assumption that, for some reasons, yellow and zólty are limited in their usage.

\begin{tabular}{|l|l|l|l|l|}
\hline $\begin{array}{l}\text { Berlin \& Kay } \\
(1969)\end{array}$ & BNC (2008) & $\begin{array}{l}\text { COCA } \\
(2008)\end{array}$ & $\begin{array}{l}\text { PELCRA corpus } \\
(2008)\end{array}$ & PWN corpus (2008) \\
\hline $\begin{array}{l}\text { BLACK/ } \\
\text { WHITE } \\
\text { WHITE } \\
\text { IBLACK }\end{array}$ & BLACK & WHITE & BIALY & BIALY \\
\cline { 2 - 5 } & WHITE & BLACK & CZARNY & CZARNY \\
\hline
\end{tabular}




\begin{tabular}{|c|c|c|c|c|}
\hline $\begin{array}{l}\text { Berlin \& Kay } \\
(1969)\end{array}$ & BNC (2008) & $\begin{array}{l}\text { COCA } \\
(2008)\end{array}$ & $\begin{array}{ll}\text { PELCRA corpus } \\
(2008)\end{array}$ & PWN corpus $(2008)$ \\
\hline$R E D$ & RED & RED & CZERWONY & CZERWONY \\
\hline \multirow{2}{*}{$\begin{array}{l}\text { GREEN/ } \\
\text { YELLOW } \\
\text { YELLOW } \\
/ \text { /GREEN }\end{array}$} & GREEN & GREEN & ZIELONY & ZIELONY \\
\hline & BLUE & BROWN & SZARY & SZARY \\
\hline BLUE & BROWN & BLUE & NIEBIESKI & $\dot{Z} O ́ L T Y$ \\
\hline BROWN & GREY/GRAY & GRAY/GREY & ŹÓLTY & NIEBIESKI \\
\hline \multirow{4}{*}{$\begin{array}{l}\text { GREY } \\
\text { ORANGE } \\
\text { PURPLE } \\
\text { PINK } \\
\text { (in any order) }\end{array}$} & YELLOW & YELLOW & BRAZZOWY & BRAZOWY \\
\hline & PINK & ORANGE & $R \dot{O} \dot{Z} O W Y$ & RÓं் $O W Y$ \\
\hline & ORANGE & PINK & POMARAŃCZOWY & POMARAŃCZOWY \\
\hline & PURPLE & PURPLE & FIOLETOWY & FIOLETOWY \\
\hline
\end{tabular}

Tab. 2: The sequence of BCTs according to corpus frequencies (surnames omitted).

Previous quantitative analyses reveal that this BCT occupies a lower position in terms of corpus frequencies in both languages. In a study by Pawłowski (2006: 45) the distributive ranking of the Polish eleven BCTs in corpora exhibits the following sequence: black, white, red, green, blue, grey, brown, yellow, pink, orange, violet, in which żóty ('yellow') appears to be less frequent than terms for blue, grey and brown. Although the statistics for this Polish BCT are less striking elsewhere (see Tab. 2), relegating żótty to the seventh place on the basis of overall frequencies in the PELCRA corpus, and the sixth place in the PWN corpus, the question still remains: why are yellow and żólty, while referring to a highly distinctive and salient colour, so poorly represented in the two languages in question? Even in the realm of aesthetics "yellow never seems to have been regarded as a noble colour in the West until the end of the Middle Ages, and it is apparently still regarded as one of the least pleasurable of individual hues" (Burnham et al. 1963: 209-210 in Gage, 2006: 15). Can this averseness towards yellow be traced, and convincingly explained, on the basis of available linguistic data?

\section{Method}

In order to obtain a plausible explanation for this intriguing phenomenon of a significant deviation in the universal pattern of colour distribution in the lexicon, an insight into the semantics of yellow and żótty is indispensable. In spite of previous linguistic research into the semantics of these terms (Wierzbicka 1996: 317: Waszakowa 2003; Tokarski 2004; Stanulewicz 2006), a need for a more detailed study, combining both qualitative and quantitative approaches within a cognitive semantic framework, is highly justified. For this reason, the following analysis investigates: (a) instances of yellow and zótty in large samples (1,500 citations) extracted from electronic online corpora; (b) collocational patterns and other linguistic data in search of the prototypical entities, expected to motivate both central and peripheral meanings; (c) etymologies which might shed some light on the primary motivations and associations behind today's categories of yellow and zólty; (d) lexicographic material referring to natural objects and phenomena 
as perceptual reference points for this and other colour terms; (e) frequencies of attested meanings of the investigated BCT in either language. This procedure is intended to provide a conceptual picture for the categories of yellow and zótty; one which is likely to account for the weak status of these colour terms in their languages.

\section{Research}

Colour terms cannot be analysed in isolation, whether from a perceptual, conceptual or cultural perspective. Accordingly, this section starts with a brief appraisal of the other five BCTs in English and Polish, with reference to their prototypes. Table 3 illustrates a rather consistent pattern of correlations between historical meanings, 'best exemplars' of respective colours as indicated by dictionaries, and corpus findings. With very few exceptions, the data obtained so far allow determination of the prototypical core for each respective category.

\begin{tabular}{|c|c|c|c|c|}
\hline $\begin{array}{l}\text { BASIC } \\
\text { COLOUR } \\
\text { TERM }\end{array}$ & $\begin{array}{l}\text { HISTORICAL } \\
\text { MEANING(S) }\end{array}$ & $\begin{array}{l}\text { DICTIONARY } \\
\text { DATA }\end{array}$ & $\begin{array}{l}\text { CORPUS DATA } \\
\text { (COLLOCATES) }\end{array}$ & $\begin{array}{l}\text { PROTOTYPE(S) } \\
\text { FOR } \\
\text { THE } \\
\text { CATEGORY }\end{array}$ \\
\hline BLACK & $\begin{array}{l}\text { dark; } \\
\text { to } \\
\text { gleam }\end{array}$ & $\begin{array}{l}\text { darkness/night, } \\
\text { soot, coal, } \\
\text { printing ink }\end{array}$ & $\begin{array}{l}\text { night, black } \\
\text { organic } \\
\text { substances, } \\
\text { black birds }\end{array}$ & $\begin{array}{l}\text { NIGHT, } \\
\text { BLACK } \\
\text { ORGANIC } \\
\text { SUBSTANCES }\end{array}$ \\
\hline CZARNY & $\begin{array}{l}\text { colour of coal; } \\
\text { dark, gloomy, } \\
\text { evil; dirty }\end{array}$ & $\begin{array}{l}\text { coal, } \\
\text { darkness/night, } \\
\text { soot }\end{array}$ & $\begin{array}{l}\text { black organic } \\
\text { substances, } \\
\text { black birds, } \\
\text { night, ebony }\end{array}$ & $\begin{array}{l}\text { BLACK } \\
\text { ORGANIC } \\
\text { SUBSTANCES, } \\
\text { NIGHT }\end{array}$ \\
\hline WHITE & $\begin{array}{l}\text { to shine, } \\
\text { to gleam, } \\
\text { bright, white }\end{array}$ & $\begin{array}{l}\text { snow, milk, salt } \\
\text { egg white, bone }\end{array}$ & $\begin{array}{l}\text { snow, sheet, } \\
\text { paper, } \\
\text { ghost, milk }\end{array}$ & $\begin{array}{l}\text { SNOW, } \\
\text { DAYLIGHT, }\end{array}$ \\
\hline BIAŁY & $\begin{array}{l}\text { white, light, } \\
\text { shining }\end{array}$ & snow, milk & $\begin{array}{l}\text { snow, flour, } \\
\text { chalk }\end{array}$ & $\begin{array}{l}\text { SNOW, } \\
\text { DAYLIGHT }\end{array}$ \\
\hline RED & red & $\begin{array}{l}\text { (fresh) blood, } \\
\text { fire, } \\
\text { leaves in } \\
\text { autumn, } \\
\text { ripe fruits }\end{array}$ & $\begin{array}{l}\text { blood, } \\
\text { berries, } \\
\text { fire, }\end{array}$ & $\begin{array}{l}\text { BLOOD, } \\
\text { FIRE }\end{array}$ \\
\hline CZERWONY & $\begin{array}{l}\text { of (the colour) } \\
\text { of blood, (of } \\
\text { the face) } \\
\text { blushing }\end{array}$ & $\begin{array}{l}\text { the first (or } 7^{\text {th }} \text { ) } \\
\text { colour in the } \\
\text { rainbow }\end{array}$ & $\begin{array}{l}\text { blood, } \\
\text { beetroot, } \\
\text { red wine, }\end{array}$ & $\begin{array}{l}\text { BLOOD, } \\
\text { FIRE }\end{array}$ \\
\hline GREEN & $\begin{array}{l}\text { to grow, } \\
\text { to become } \\
\text { green }\end{array}$ & $\begin{array}{l}\text { grass, } \\
\text { foliage }\end{array}$ & $\begin{array}{l}\text { grass, emerald, } \\
\text { leaves, }\end{array}$ & $\begin{array}{l}\text { HERBAGE, } \\
\text { LEAVES }\end{array}$ \\
\hline
\end{tabular}




\begin{tabular}{|c|c|c|c|c|}
\hline $\begin{array}{l}\text { BASIC } \\
\text { COLOUR } \\
\text { TERM }\end{array}$ & $\begin{array}{l}\text { HISTORICAL } \\
\text { MEANING(S) }\end{array}$ & $\begin{array}{l}\text { DICTIONARY } \\
\text { DATA }\end{array}$ & $\begin{array}{l}\text { CORPUS DATA } \\
\text { (COLLOCATES) }\end{array}$ & $\begin{array}{l}\text { PROTOTYPE(S) } \\
\text { FOR } \\
\text { THE } \\
\text { CATEGORY }\end{array}$ \\
\hline ZIELONY & $\begin{array}{l}\text { to shine; } \\
\text { yellow, green, } \\
\text { grey, blue }\end{array}$ & $\begin{array}{l}\text { fresh grass, } \\
\text { emerald }\end{array}$ & $\begin{array}{l}\text { young grass, } \\
\text { lawn, } \\
\text { bottle glass, } \\
\text { unripe fruits }\end{array}$ & $\begin{array}{l}\text { HERBAGE, } \\
\text { LEAVES }\end{array}$ \\
\hline BLUE & $\begin{array}{l}\text { light coloured, } \\
\text { blue, blond, } \\
\text { yellow }\end{array}$ & $\begin{array}{l}\text { (clear) sky, } \\
\text { (deep) sea }\end{array}$ & $\begin{array}{l}\text { sky, sea, eyes, } \\
\text { cornflowers }\end{array}$ & $\begin{array}{l}\text { SKY, } \\
\text { (SEA) WATER }\end{array}$ \\
\hline NIEBIESKI & $\begin{array}{l}\text { of the sky } \\
\text { and heaven }\end{array}$ & $\begin{array}{l}\text { (clear) sky } \\
\text { blue flax flower }\end{array}$ & $\begin{array}{l}\text { sky, } \\
\text { cornflowers, sea }\end{array}$ & $\begin{array}{l}\text { SKY, } \\
\text { (WATER) }\end{array}$ \\
\hline
\end{tabular}

Tab. 3: Review of the prototypical exemplars and etymological data for the primary BCTs in English and Polish (Gieroń-Czepczor forthcoming).

The results presented in Table 4, which conclude my previous research (GieronCzepczor (2008, 2010, forthcoming), have also been confirmed in recent literature by inter alia Niemeier, 1998, 2007; Peprnik 2005; Philip 2006; Pietrzak-Porwisz, 2006; Sarapik, 1997; Sassoon 1992; Stanulewicz 2006, 2007, 2009; Steinvall 2002; Tatoj 2006; Teodorowicz-Hellman 2003; Tokarski 2004; Tribushinina 2008; Vaňková, 2000; Verosub 1994; Waszakowa 2000a, 2000b, 2003a, 2003b, 2003c; Wierzbicka 1990, 1996. These clearly indicate that the other five primary BCTs are conceptually motivated by entities and phenomena which conform to common associations.

\subsection{The conceptual core}

The conceptual centre of a lexical unit, conveniently termed 'the prototype' (Heider 1972; Rosch 1975, 1978; Rosch and Mervis 1975; Lakoff 1987), is understood as "the basic reading", "the center of semantic cohesion in the category" (Geeraerts, 2001: 3), characterized by "psychological salience, relative, frequency of use, interpretative advantageousness" (ibid.). Wierzbicka (1996: ch.10) defines the prototype as "phenomena prevalent and distinctive to the environment", and with reference to yellow the author (ibid.: 317 ) suggests an explication which indicates the sun as the only salient natural entity central to our understanding of the category. This claim does not account for the explicit negative meanings that yellow and zólty exhibit. The prototype extended to "a psychological object or process" (Coleman \& Kay, 1981: 43) or "a mental representation" (Ungerer \& Schmid, 1996: 42) allows for inclusion of seasonal changes (Waszakowa 2003) and the process of ageing (Tokarski 2004) into the centre of the categories yellow and żółty. 


\subsubsection{Lexicographic evidence}

A review of dictionary definitions, presented in Table 4, provides information on what is seen as the best exemplar of the colour. The range of entities indicated is, on the one hand, fairly wide (including lemon, butter, yolk and gold as the most salient referents). On the other hand, it does not indicate any object or process which might seem to motivate the usages of yellow and/or zólty; especially those based on metonymic and metaphorical mappings. Notably, the sun appears in one definition only, following lemon and gold.

\begin{tabular}{|l|l|}
\hline \multicolumn{1}{|c|}{ English and American dictionaries } & \multicolumn{1}{c|}{ Natural prototypes } \\
\hline $\begin{array}{l}\text { Oxford Advanced Learner's Dictionary of } \\
\text { Current English (1974) }\end{array}$ & gold, yolk \\
\hline $\begin{array}{l}\text { Webster's Encyclopedic Unabridged } \\
\text { Dictionary of the English Language (1989) }\end{array}$ & butter, lemon \\
\hline The American Heritage Dictionary (1994) & $\begin{array}{l}\text { ripe lemons, the hue of the visible } \\
\text { spectrum between orange } \\
\text { and green }\end{array}$ \\
\hline $\begin{array}{l}\text { Longman Dictionary of Contemporary } \\
\text { English (2003) }\end{array}$ & butter, yolk \\
\hline $\begin{array}{l}\text { Oxford English Dictionary (no date) } \\
\text { Cambridge Advanced Learner's Dictionary } \\
\text { (2008) }\end{array}$ & $\begin{array}{l}\text { gold, butter, yolk, flowers, } \\
\text { the hue of the visible spectrum } \\
\text { between orange and green }\end{array}$ \\
\hline $\begin{array}{l}\text { Merriam-Webster's Online Dictionary(no } \\
\text { date) }\end{array}$ & $\begin{array}{l}\text { ripe lemons or sunflowers, } \\
\text { the part of the spectrum lying } \\
\text { between green and orange }\end{array}$ \\
\hline \multicolumn{1}{|c|}{ Polish dictionaries } & $\begin{array}{l}\text { Natural prototypes } \\
\text { the third colour in the rainbow, } \\
\text { lemon }\end{array}$ \\
\hline \begin{tabular}{l} 
Stownik języka polskiego (1983) \\
lemon, buterrcup, yolk \\
\hline $\begin{array}{l}\text { Uniwersalny stownik języa polskiego PWN } \\
\text { (2003) }\end{array}$
\end{tabular} \\
\hline
\end{tabular}

Tab. 4: Prototypes of yellow and żótty in dictionary definitions

\subsubsection{Etymological data}

Unlike green, the etymology of which clearly suggests associations with vegetation (PIE * ghre- meant "to grow, to become green"), which conceptually shapes the semantic category of green - yellow and żótty derive from a shared proto Indo-European root *ghel-, with the meaning 'yellow, green' (Harper 2001) or 'yellow, green, gray, blue' and 'to shine' (Pokorny,1959: 429-434); a colour term itself even if one representing a wider reference, encompassing the quantitative (saturation) and qualitative (hue) dimensions of a stretch of the colour spectrum. As such, the original term does not 
denote any object or phenomenon which might be responsible for the connotations that yellow and źóty reveal nowadays, although the 'shiny' quality plays a significant role in further analysis. This diachronic perspective, however, explains the conceptual closeness between yellow/żótty and green/zielony in their references to vegetation and unhealthy human complexion. Another fact, attested in the history of żótty, relates this colour term to gold; Proto-Slavonic żtt (or żolt) is cognate with złoto (Brückner 1998).

\subsubsection{Collocational patterns}

One method of identification of prototypical reference points in corpora is to investigate collocates in the similes as yellow as, żótty jak and yellow/żótty with, which are expected to indicate prototypical exemplars of yellowness and popular connotations of the investigated BCT. In samples of 1,500 citations for yellow in the BNC and zólty in the PWN corpus, the following results have been obtained:

- 44 similes (as) yellow as include: butter, skin, bananas, sulphur, lights, cheese and terror;

- 45 similes zótty jak also fail to indicate a prototypical entity. However, the repeated collocate wosk ('wax') seems to emphasise the negative connotations of żółty as the colour of skin characteristic of a sick or elderly person;

- 20 relevant citations for yellow with indicate the following collocates: age (10), egg (2), saffron (2), autumn colours (1), bile (1), pollen (1), disease (1) and flowers (1);

- $\quad$ Merely 5 instances of żólty od collocate with: sulphur, dandelion, lights, silt and tiredness.

Based on this evidence, it would seem that in the wide array of natural substances, fruit, flowers and negative associations with sickly skin, no single entity plays the role typically attributed to categorical prototypes. Most importantly, the sun is conspicuously absent in this material.

\subsubsection{Where is the sun in the semantics of yellow and żólty?}

The evidence for the prototypicality of the sun with reference to the categories of yellow and zólty is scarce; hard to defend unless an intuitive approach - espoused by Wierzbicka $(1990,1992,1996)$ - is accepted. With a focus on corpus data based on varied, real-language material, insistence on the prototypicality of the sun is no longer plausible. The above-mentioned data appear to disprove those pre-existing intuitions which associate the cognitive categories of yellow and żolty with the sun as the prototype. However, this observation is not meant to reject the 'sunny side' of yellow altogether. The sun does appear in the semantics of yellow/żótty, yet extremely rarely and mostly indirectly. For example, the adjective yellow (in 2929 citations in the BNC) is frequently preceded by other adjectives which stress the luminosity of the colour (frequencies in brackets): bright (79), luminous (33), white (33), and golden (32). However, yellow as a collocate with the noun sun, has only 20 results in a 4 left and right collocates search in 3128 citations, in which only 7 are relevant with the colour as an 
attribute of the noun. A similar search for żótty yields 3 instances in 2500 citations including stońce ('sun'). Moreover, it seems that yellow/źótty tend to describe weaker or filtered sunshine as in:

(1) barwa słońca przy zachodzie jest żółta, złocista lub różowa (PWN)

"the colour of the sun is yellow, golden or pink at sunset";

(2) the last sunset is orange and yellow, then shades of purple (BNC)

(3) the yellow glow of the warm sun through your closed eyes.

White and biaty, it can be argued, are more common in descriptions of full sunshine, as well as in those of sunlit places and objects. Perceptually, the quality of the yellow hue can be associated with sunshine, as in stoneczna żótć ('sunny yellow') and ciepła żótć ('warm yellow) which are consistent with intuitively positive associations of the colour with the sun. They are, nevertheless, unattested in the available corpus data, and not productive in phraseological units based on 'sunny' connotations.

Moreover, linguistic material offered by the corpora tends to suggest negative associations that indirectly link yellow and zótty with the sun. The sun might be seen as degenerative, as in collocations of yellow and żótty with nouns denoting plants, paper and cloth. Yellowed grass and leaves, like the pale yellowish skin of the elderly and sick, inevitably evoke negative associations with the passing of time and death, hence sickly yellow in descriptions of eyes and complexion attested in the concordance for yellow in the $\mathrm{BNC}$, and its equivalent, chorobliwie żótty, in the PWN sample.

Therefore, the sun, even if present in the concept of yellow/żótty, evokes ambivalent connotations, as previously noted by Waszakowa (2003: 110). On the basis of a study of colour terms in poetry, Tokarski (2004) notes the predominance of negative associations in the usages of zólty, which - as he claims - arise from the image of autumnal changes in nature. These suggestions, more convincing than those based on popular associations, and combined with the qualitative and quantitative analyses below, confirm the problematic status of the sun within the categories of yellow and zótty.

\section{Quantitative data and discussion}

The following is a summary of an investigation into concordance data for adjectival forms of yellow in the British National Corpus, and żótty in the PWN Korpus Języka Polskiego. A manual analysis of the senses of the BCT in question was based on samples of 1,500 citations extracted from corpora. With a few exceptions, each sample provided enough contextual evidence to enable a reliable determination of meanings, whose frequencies are presented in Table 5.

\begin{tabular}{|c|r|r|}
\hline $\begin{array}{c}\text { Literal, metonymic and metaphorical senses of yellow and } \\
\dot{z} \text { ótty in 1,500 corpus citations }\end{array}$ & $\begin{array}{c}\text { BNC } \\
\text { sample }\end{array}$ & $\begin{array}{c}\text { PWN } \\
\text { sample }\end{array}$ \\
\hline NATURALLY YELLOW, ORANGE, BROWN(ISH) etc & $\downarrow$ & $\downarrow$ \\
\hline > WILDLIFE AND ENVIRONMENTAL ELEMENTS & $\mathbf{3 6 3}$ & $\mathbf{1 3 2}$ \\
\hline > OF HUMAN SKIN, RACE & $\mathbf{7}$ & $\mathbf{2 7}$ \\
\hline > OF HAIR, FUR & $\mathbf{2}$ & $\mathbf{4}$ \\
\hline
\end{tabular}




\begin{tabular}{|c|c|c|}
\hline $\begin{array}{c}\text { Literal, metonymic and metaphorical senses of yellow and } \\
\dot{z} \text { źtty in } 1,500 \text { corpus citations }\end{array}$ & $\begin{array}{c}\text { BNC } \\
\text { sample }\end{array}$ & $\begin{array}{l}\text { PWN } \\
\text { sample }\end{array}$ \\
\hline$>$ OF EYES & 7 & 3 \\
\hline > OF EXCRETION, DISCHARGE, PUS, INFECTION & 1 & 5 \\
\hline$>$ OF FAT AND GREASE & 1 & 4 \\
\hline$>$ OF SAND, EARTH, STONE and ROCKS & 23 & 19 \\
\hline$>$ OF GOLD & 2 & 4 \\
\hline FADED AND/OR YELLOWED & $\downarrow$ & $\downarrow$ \\
\hline$>$ OF PLANTS IN AUTUMN & 6 & 9 \\
\hline$>$ OF PLANT DISEASE & 3 & 1 \\
\hline$>$ OF CLOTH, PAPER & 1 & 7 \\
\hline$>$ OF SKIN & $\downarrow$ & $\downarrow$ \\
\hline > INDICATING OLD AGE AND/OR EXHAUSTION & 6 & 17 \\
\hline > INDICATING DISEASE & 9 & 19 \\
\hline$>$ BRUISED & 5 & $\mathbf{0}$ \\
\hline$>$ OF TEETH AND NAILS & 4 & 11 \\
\hline (OF LIGHT) DIM, YELLOWISH (AGAINST THE DARK ) & 19 & 21 \\
\hline DRESSED IN YELLOW & $\mathbf{0}$ & $\mathbf{1}$ \\
\hline UNDER THE INFLUENCE OF YELLOW BILE & 2 & 2 \\
\hline > EMANATING FEELINGS OF JEALOUSY, ANGER & 1 & 2 \\
\hline > CRAVEN, COWARDLY & 1 & $\mathbf{0}$ \\
\hline > DISHONOURABLE, DISGRACEFUL & $\mathbf{0}$ & 8 \\
\hline PERTAINING TO A POLITICAL PARTY & 5 & 3 \\
\hline COLOUR OF ATTENTION & 9 & 2 \\
\hline > CAUTION, WARNING & 208 & 124 \\
\hline$>$ SENSATIONAL & 2 & $\mathbf{0}$ \\
\hline
\end{tabular}

Tab. 5: Meanings of yellow and żótty in the BNC and PWN Korpus concordances.

The quantitative results are represented in the form of a graph (Fig. 2), with related meanings partly subsumed under joint headings, for easier comparison of frequencies within one language and direct cross-linguistic comparison. 


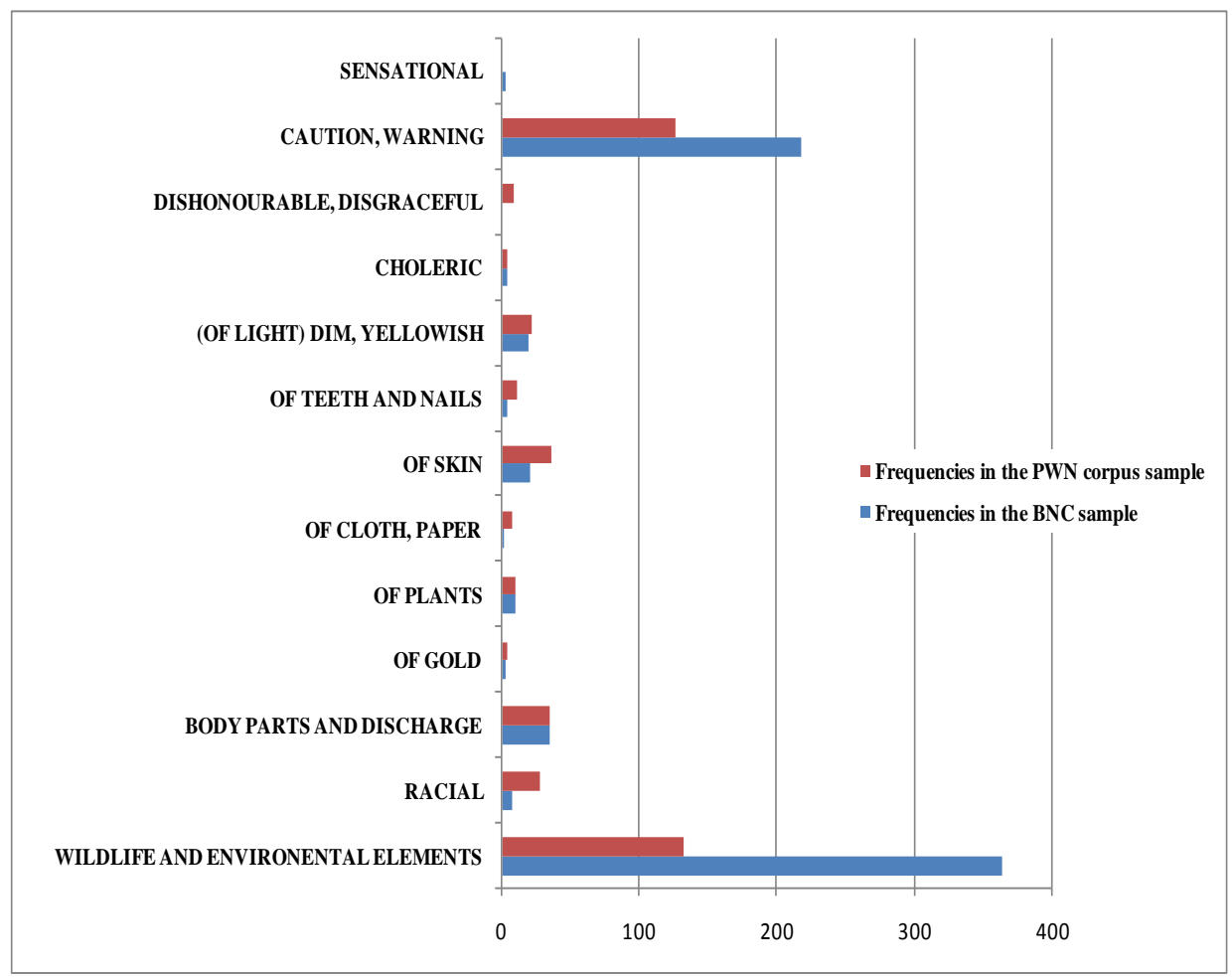

Fig.2: The occurence of respective senses of yellow and żótty in corpus samples of 1,500 citations.

A significant majority of uses of both yellow and żótty can be traced to their referential function as a colour term. In this respect either term collocates frequently with nouns denoting a wide range of natural entities: flowers, birds, vegetables, cattle, rock and stone, fruit, leaves, grass, and sand. These collocations suggest yellow and żótty in their literal usages refer to a fairly ample stretch of the colour spectrum, and - via the metonymic mapping known as generalization - signify shades ranging between green and brownish. No single object or natural kind dominates in the frequencies attested, which corroborates the assumption that the prototype for the categories of yellow and zólty cannot be found among distinctive environmental entities.

Yellow, alongside red, belongs to the most conspicuous of colours, whether natural or artificial:

(4) the dried-up river bed is ablaze with yellow and pink stonecrop.

(5) Some retailers use distinctive packaging for their own brands, e.g. one supermarket chain packaged everything in bright yellow.

This characteristic makes yellow pervasive in signs and signals. While neutral in its semiotic function (neither red, i.e. "stop", nor green, i.e. "go") yellow does stand out perceptually and, as such, is suitable for indicating limitations, warnings or - more rarely 
- danger. Yellow cards/żółte kartki, yellow traffic lights, yellow flags and double yellow lines are conventional enough to be further exploited in figurative usage:

(6) "Yellow card" for Tories over ticket touts laws

(7) ... od kilku lat Europa stoi na żółtym świetle ...

"For several years Europe has been standing at the yellow light..."

(8) Double yellow lines trap jailbird after 14 years on the run.

On the whole, yellow in its signaling function, as well as in its metonymic and metaphorical extensions, can be seen as fairly negative, evoking connotations of arrest or interruption.

With reference to the yellowish colour of human skin in racial contexts, yellow and żólty tend to be metonymically applied in a depreciatory, non-neutral way, unlike black/czarny and white/biaty. English and Polish reflect a shared fear of an Asiatic invasion - either military or economic - as in the well-entrenched phrases: żólta dżuma ('yellow plague') and yellow peril. The latter, although believed to have been coined by William II of Germany (Hunter 1989), is deeply rooted in the image of the yellow race as a threat:

(9) ...zaleje nas żółta rasa.

('The yellow race will flood us')

The readings of 'faded' and 'yellowed' occupy an important place in the semantics of the BCT in both languages. As an indication of age, disease or poor hygiene, yellow and zólty are fraught with overtly negative connotations which link the physical state with emotional misery:

(4) ... wyschłem duszą na żółty szkielet ... (PWN)

"... my soul withered into a yellow skeleton ..."

(5) ... wychudzony i żółty od nieprzespanych nocy. (PWN)

"...emaciated and yellow with sleepless nights."

(6) Frankenstein's creation was hideous. He had yellow skin, watery eyes, black hair ... (BNC)

Further usage of yellow as 'contemptible' occurs in yellow dog contract, which although attested in modern English dictionaries - has not been attested in the corpus material. An interpretation for the presence of yellow in the phrase may refer to the colour of the canine coat which, if yellow, indicates a mixed breed dog; cowardly and despised (Hendrickson 2008: 909):

The yellow dog, generally considered to be a cowardly common cur or mongrel, has long been a symbol of utter worthlessness in America. The term yellow dog has been used in expressions of contempt since at least 1833, when it is first so recorded, and toward the late 19th century it began to be heard in the term yellow-dog contract.

Morphologically unrelated, yet conceptually motivated by negative associations with fading, words like withering ('scornful', 'contemptuous', 'humiliating') and off-colour stand in clear contrast to adjectives denoting a truly sunny disposition, referred to as 'cheerful', 'bright' and 'animated.' This strand of linguistic evidence provides one more argument against any positive motivation of the sun for yellow and zótty viewed as conceptual constructs.

Moreover, when applied with reference to light or lights, both terms are not - as might be expected - typically found in collocations with the sun. Instead, each term 
denotes the quality of celestial objects, as in "świecił żółty Jowisz", PWN ("the yellow Jupiter shone") or the light shed by weak sources:

(7) $\quad \ldots$ the storm lantern threw its uneven yellow light

(BNC), whereas full daylight or bright sunshine are described by terms implying luminosity and intensity, e.g. golden, zloty (złocisty, złotawy), white and biaty ('white').

The previously listed conceptual mappings involving yellow and żółty are mainly pure metonymies, if conceptual blends such as yellow peril are excluded. As reference sources and corpus data indicate, metaphorical mappings in the usage of yellow result in solely negative meanings, such as: 'emanating feeling of jealousy, anger' and 'craven, cowardly'. Merriam-Webster Dictionary Online lists the following adjectives as synonymous with yellow: chicken, chickenhearted, chicken-livered, craven, dastardly, gutless, lily-livered, milk-livered [archaic], poltroon, pusillanimous, recreant, spineless, unheroic, cowardly. All these are explicitly pejorative and consistent with the negative overtones present in yellow-bellied, yellow coward and yellow streak. The source of the underlying metaphor - or, as some might argue, SYMPTOM FOR ITS CAUSE metonymy - is the Theory of Four Humours, present in European culture since antiquity, further elaborated by Galen in the Middle Ages, and immensely popular in medicinal practice throughout the centuries. According to the doctrine, an excess of yellow bile in the human body accounts for an inclination towards anger. Although rejected by modern medicine, it permeates what is known as folk medicine, and - more importantly - still has an immense cultural reach, being productive in the interpretation of human nature.

The same motivation, without clear evidence in the form of well-established phraseology incorporating źótty, is present in the morphological (and conceptual) correlation between bile and the yellow colour: żótć, an uncountable feminine noun, signifies both of them. As etymological data suggest, żótc with the meaning 'bile' is an instance of metonymy, mapping the colouring onto the substance and further onto its (negative) properties and the symptoms evoked. Thus, due to a culture-induced conceptual shift, żótć is used within the domain of emotions with reference to an exhibition of distress or reproach:

(8) - Defilada? - napełniła słowo żółcią. - Za niecałą godzinę przed tym pomnikiem, co go nikt nie chce ...

"- A parade? - she filled the word with bile. - In less than an hour in front of the monument that nobody wants ..."

Like red used metonymically for blood, żótć retains the ontological property of the entity from the source domain. Therefore, the state of irascibility is pictured as an abundance or overflow of the liquid, whereas its release helps one regain an emotional balance:

(9) W miarę odpływu żółci następowało rozjaśnienie umysłu i pamięci.

"As the bile receded, clarity of the mind and memory came".

The usages of żótc attested in the PWN sample reveal its synaesthetic nature: the term evokes a complexity of associations with bile; its colour and taste, correlating yellowness (domain of vision) with bitterness (domain of taste):

(10) Na zasłonie żółciło się gorzko palące słońce

"The bitterly glaring sun(shine) yellowed the curtain".

Bitterness as an emotional state rendered by the noun żótć is fairly frequent in Polish:

(11) Mrok i żółć chwil bieżących ... 
"The gloom and bitterness of the current moments ..."

(12) Po bezludnych wąskich trotuarach przemykali gdzieniegdzie samotni żółci przechodnie.

"Lonely yellow passers-by were scurrying here and there along deserted narrow pavements".

\section{Conclusions}

Colour terms do not have a purely referential role; they are used in order to express "a cultural unit or concept." (Eco 1985: 160). The category of yellow, unlike the other primary BCTs, is not shaped by the primeval fear of natural phenomena such as the dark (black) or fire (red). Nor is it influenced by the imagery of a distinctive entity bearing a colour, as is the case with the sky, water (blue) and snow (white). The metaphorical status of yellow is the product of a complex belief in the special role played by a bodily substance upon the emotional constitution of humans; a belief widely-acknowledged and deeply rooted in European culture since medieval times. Its role cannot be overestimated: it has caused yellow to become synonymous with emotional imbalance, jealousy, cowardice and treachery. The concept, frequently fostered by aesthetic symbolism, has left negative connotations in culturally shaped perceptions of yellow in both Germanic and Slavonic languages.

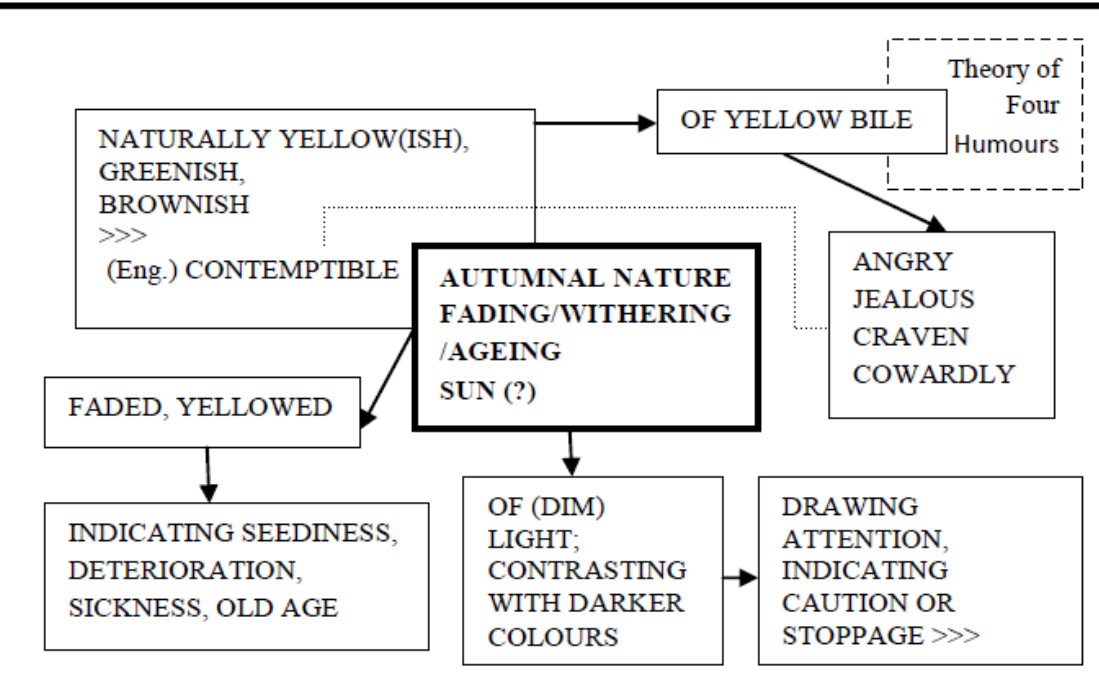

Fig. 3 A simplified conceptual network for yellow and źólty. 
Categorial structures of yellow and żótty seem to centre around blurred or weak prototypes, among which the role of the sun can easily be challenged, resulting in impoverished patterns of meaning extensions, all of which bear negative connotations. The basic imagery for yellow and żóty in nature is that of fading, drying, withering and sickness. Metaphorical usages do not go beyond negative evaluative connotations of treachery and cowardice. The historically attested shiny quality of $*_{-}$ghel seems to have been lost by yellow and żótty in favour of adjectives related to words for gold: golden, złoty, złocisty and złotawy.

\section{References}

Berlin, Brent \& Paul Kay (1969). Basic Color Terms: Their Universality and Evolution. Berkeley: University of California Press.

Brückner, Aleksander (1998). Słownik etymologiczny języka polskiego. Warszawa: Wiedza Powszechna.

Burnham, Robert W., Randall M. Hanes \& C. James Bartleson (1963). Color, a guide to basic facts and concepts. New York: Wiley.

Coleman, Linda \& Paul Kay (1981)."Prototype Semantics: The English Word Lie”. Language, 57, No. 1, 26-44. Available at: http://www.jstor.org/stable/414285.

Dubisz, Stanisław (ed.) (2003). Uniwersalny słownik języka polskiego PWN. Warszawa: Wydawnictwo Naukowe PWN.

Eco, Umberto (1985). "How Culture Conditions the Colours We See". In M. Blonsky (Ed.), On Signs (157-175). Baltimore: Johns Hopkins University Press.

Gage, John (2006). Color and Meaning: Art, Science, and Symbolism. London: Thames and Hudson.

Gieron-Czepczor, Ewa (2008). "Contrastive semasiological analysis of white and biaty". Studia Filologiczne, 2, 19-48.

Gieron-Czepczor, Ewa (2010). "Red and czerwony as cognitive categories: a corpus based study". SKASE Journal of Theoretical Linguistics [online]. vol. 7, no. 3, 19-52. Available on web page <http://www.skase.sk/Volumes/JTL17/pdf_doc/02.pdf>. ISSN 1339-782X.

Gieroń-Czepczor, Ewa (forthcoming). A corpus-based cognitive-semantic analysis of the primary basic colour terms in English and Polish. Racibórz: Państwowa Wyższa Szkoła Zawodowa w Raciborzu.

Harper, Douglas (2001-2010). Online Etymology Dictionary. Available at: http://www.etymonline.com.

Heider, Eleanor R. (1972). "Universals of Color Naming and Memory". Journal of Experimental Psychology, 93, 10-20.

Hendrickson, Robert (2008). The Facts On File Encyclopedia of Word and Phrase Origins (4th ed.). New York: Facts on File.

Hunter, Janet (1989). The Emergence of Modern Japan: An Introductory History since 1853. London: Longman.

Lakoff, George (1987). Women, Fire, an Dangerous Things. What Categories Reveal about the Mind. Chicago and London: The University of Chicago Press. 
Niemeier, Susanne (2007). "From blue stockings to blue movies. Color metonimies in English”. In M. Plümacher \& P. Holz (Eds.), Speaking of Colors and Odors (141154). Amsterdam: John Benjamins Publishing Company.

Pawłowski, Adam (2006). "Quantitative linguistics in the study of colour terminology. A research report”. In C.P. Biggam, Ch. Kay \& N. Pitchford (Eds.), Progress in Colour Studies: Language and Culture. Vol I (37-56). Amsterdam/Philadelphia: John Benjamins Publishing Company.

Peprník, Jaroslav (2005). "The colour 'green' in English language and literature". Patterns. A Festschrift for Libuše Dušková, 143-155. Praha: Univerzita Karlova.

Philip, Gill (2006). "Connotative meaning in English and Italian. Colour-Word Metaphors". Metaphorik.de 10 [online], 59-93. Available on web page http://www.metaphorik.de/10/philip.htm.

Pietrzak-Porwisz, Grażyna (2006). "Semantyka bieli w języku polskim i szwedzkim". Studia Linguistica Universitatis Iagiellonicae Cracoviensis 123, 135-154.

Pokorny, Julius (1959). Indo-European Etymological Dictionary (Indogermanisches Etymologisches Woerterbuch). Available at: http://dnghu.org/indoeuropean.html

Rosch, Eleanor (1975). "Cognitive representation of semantic categories". Journal of Experimental Psychology 104(3), 192-233.

Rosch, Eleanor (1978). "Principles of Categorization". In E. Rosch \& B. Lloyd (Eds.), Cognition and categorization (27-48). Hillsdale, NJ: Lawrence Erlbaum.

Rosch, Eleanor \& Carolyn B. Mervis (1975). "Family resemblances: Studies in the internal structures of categories". Cognitive Psychology 7, 573-605.

Sarapik, Virve (1997). "Red: The Colour and the Word". Folklore: Electronic Journal of Folklore, 3, 93-130. Retrieved May 2, 2009 from: www.ceeol.com.

Sassoon, Joseph (1992). "Colors, Artifacts, and Ideologies". In P. Gagliardi, Symbols and artifacts: views of the corporate landscape (169-184). Berlin: de Gruyter.

Stanulewicz, Danuta (2006). "Regional diversity of the reference-points for the six basic colour terms in Polish (white, black, red, green, yellow, blue) - A comparison with selected Slavic and Germanic Languages". Biuletyn Polskiego Towarzystwa Jezykoznawczego (Bulletin of the Polish Linguistic Society), 62, 199-211.

Stanulewicz, Danuta (2007). "Polish colour terms referring to blue: A corpus view". In U. Magnusson, H. Kardela \& A. Głaz (eds.), Further Insights into Semantics and Lexicography (87-100). Lublin: Wydawnictwo Uniwersytetu Marie CurieSkłodowskiej.

Stanulewicz, Danuta (2009). Colour, Culture and Language. Blue in Polish. Gdańsk: Wydawnictwo Uniwersytetu Gdańskiego.

Steinvall, Anders (2002). English Colour Terms In Context [PhD diss.]. Retrieved July 5, 2008, from: www.diva-portal.org/diva/getDocument?urn_nbn_se_umu_diva-861_fulltext.pdf

Tatoj, Cecylia (2006). El concepto del "color" en los fraseologismos españoles y polacos. Neophilologica. Vol.18, 123-130. Katowice: Wydawnictwo Uniwersytetu Śląskiego. 
Teodorowicz-Hellman, Ewa (2003). "Postrzeganie świata roślin, zwierząt i ludzi poprzez nazwę barwy żólty w języku polskim oraz gul w języku szwedzkim”. In R. Grzegorczykowa \& K. Waszakowa (Eds.), Studia z semantyki porównawczej. Nazwy barw, nazwy wymiarów, predykaty mentalne. Czesść II (135 - 150). Warszawa: Wydawnictwa Uniwersytetu Warszawskiego.

Tokarski, Ryszard (2004). Semantyka barw we współczesnej polszczyźnie. Lublin: Wydawnictwo Uniwersytetu Marii Curie-Skłodowskiej.

Tribushinina, Elena (2008). "Colour adjectives". In: Cognitive reference points. Semantics Beyond the Prototypes in Adjectives of Space and Colour. [PhD diss. ] VU University, Amsterdam. Retrieved March 5, 2009 from: http://www.lotpublications.nl/publish/articles/003021/bookpart.pdf

Ungerer, Friedrich \& Hans-Jörg Schmid (1996). An Introduction to Cognitive Linguistics. London/New York: Longman.

Vaňková, Irena (2000). "Mienić się różnymi kolorami. Zabarwienie skóry jako symbolizacja cech i stanów psychofizycznych człowieka". In R. Grzegorczykowa \& K. Waszakowa (Eds.), Studia z semantyki porównawczej. Nazwy barw, nazwy wymiarów, predykaty mentalne. Część I (105-124). Warszawa: Wydawnictwa Uniwersytetu Warszawskiego.

Verosub, Abra L. (1994). "Scarlet Letters: Metonymic Uses of the Color Red". Semiotica, 102, no. 1/2, 27-47.

Waszakowa, Krystyna (2000a). "Podstawowe nazwy barw i ich prototypowe odniesienia. Metodologia opisu porównawczego". In R. Grzegorczykowa \& K. Waszakowa (Eds.). Studia $z$ semantyki porównawczej. Nazwy barw, nazwy wymiarów, predykaty mentalne. Część I $(17-28)$. Warszawa: Wydawnictwa Uniwersytetu Warszawskiego.

Waszakowa, Krystyna (2000b). "Struktura znaczeniowa podstawowych nazw barw. Założenia opisu porównawczego". In R. Grzegorczykowa \& K. Waszakowa (Eds.), Studia z semantyki porównawczej. Nazwy barw, nazwy wymiarów, predykaty mentalne. Część I (59 - 72) . Warszawa: Wydawnictwa Uniwersytetu Warszawskiego.

Waszakowa, Krystyna (2003a). “Opis porównawczy znaczeń podstawowej nazwy barwy zielonej w języku polskim, czeskim, rosyjskim, ukraińskim i szwedzkim, wietnamskim". In R. Grzegorczykowa \& K. Waszakowa (Eds.), Studia z semantyki porównawczej. Nazwy barw, nazwy wymiarów, predykaty mentalne. Czesść II (4968). Warszawa: Wydawnictwa Uniwersytetu Warszawskiego.

Waszakowa, Krystyna (2003b). "Językowe i kulturowe odniesienia nazwy barwy żółtej we współczesnej polszczyźnie”. In R. Grzegorczykowa \& K. Waszakowa (Eds.), Studia z semantyki porównawczej. Nazwy barw, nazwy wymiarów, predykaty mentalne. Część II (99 - 122). Warszawa: Wydawnictwa Uniwersytetu Warszawskiego.

Waszakowa, Krystyna (2003c). Porównanie znaczeń podstawowych nazw barwy żółtej w języku polskim, czeskim, rosyjskim, ukraińskim i szwedzkim. In R. Grzegorczykowa \& K. Waszakowa (Eds.), Studia z semantyki porównawczej. Nazwy barw, nazwy wymiarów, predykaty mentalne. Część II (163 - 188). Warszawa: Wydawnictwa Uniwersytetu Warszawskiego. 
Wierzbicka, Anna (1990). "The meaning of color terms: Semantics, culture, and cognition". Cognitive Linguistics, 1, 99-150.

Wierzbicka, Anna (1992). Semantics, Culture, and Cognition. Universal Human Concepts in Culture-Specific Configurations. New York/Oxford: Oxford University Press.

Wierzbicka, Anna (1996). Semantics: Primes and Universals. Oxford: Oxford University Press.

Yellow. (1974). In A.S. Hornby, Oxford Advanced Learner's Dictionary (3 ${ }^{\text {rd }}$ ed.). Oxford: Oxford University Press.

Yellow. (1989). In Webster's Encyclopedic Unabridged Dictionary of the English Language. New York: Portland House.

Yellow. (1994). In The American Heritage Dictionary ( ${ }^{\text {rd }}$ ed.). New York: Dell Publishing.

Yellow. (n.d.) Oxford English Dictionary. Retrieved March 23, 2009 from http://www.oed.com.

Yellow. (n.d.) Merriam-Webster Dictionary. Retrieved March 23, 2009 from www.merriam-webster.com.

Yellow. (2003) In Longman Dictionary of Contemporary English (4 ${ }^{\text {th }}$ ed.). Harlow: Pearson Education Limited.

Yellow. (2008). In Cambridge Advanced Learner's Dictionary ( $3^{\text {rd }}$ edition). Cambridge: CUP.

Żółty. (1983). In W. Doroszewski (Ed.), Słownik języka polskiego. Warszawa: PWN.

Żółty. (2003). In S. Dubisz (Ed.), Uniwersalny słownik języka polskiego PWN. Warszawa: Wydawnictwo Naukowe PWN. 